\title{
Vitamin and mineral analysis of fish liver oil, some locally available spices and vegetables
}

S .A Bolu, O.O Balogun and F.E. Sola-Ojo

Department of Animal Production University of Ilorin, Ilorin, Nigeria. mofesola1@yahoo.com

\begin{abstract}
High Performance Liquid Chromatography (HPLC) was used to determine the vitamin and mineral contents of some locally sourced ingredients such as fish liver oil, Adansonia digitata

, Telfaria occidentalis, Celosia spp, Amaranthus cruentas leaves, Xylopia aetiopica, capsicum frutenscen, Saccharomyces cerevicae, rice bran, palm oil and colostrums. The results indicated that fish liver oil was the most potent source of vitamins $A, D, E$ and $B_{12}$ represented by $9 \times 10^{6} \mathrm{iu} / 100 \mathrm{~g}, 48000 \mathrm{icu} / 100 \mathrm{~g}, 30 \mathrm{mg} / 100 \mathrm{~g}$, and $40.5 \mathrm{mg} / 100 \mathrm{~g}$, respectively. The B-Complex vitamins were present among the spices and vegetables analyzed. Saccharomyces cerevicae was observed to a potent source of thiamin (9.4mg /100g) and niacin (41.8 mg / 100g). Capsicum spp and Telfaria occidentalis had ample amounts of riboflavin, thiamin and niacin. Rice bran had the highest amount of pyridoxine, 28.6mg/100g, while panthothenate was present more in the milk $(8.2 \mathrm{mg} / 100 \mathrm{~g})$ than other materials analysed. The mineral composition of the materials analysed showed that they have fairly uniform potency. Amaranthus cruentas was found to contain more mineral with 3.0, 1.4, 5.13, 1.10, 5.04 and 1.09\% for copper (cu), Zinc (Zn), potassium (K), Sodium (Na), Calcium (ca), and magnesium (mg), respectively. The results of the analysis indicated that vitamin and mineral potencies of these ingredients can be harnessed for the production of vitamin and mineral premix for animal feed formulation
\end{abstract}

Key words: HPLC, Natural ingredients, Spices, Vegetables, Vitamin, Minerals.

\section{Introduction}

Feeding has been a major determinant of profit in the livestock business as it accounts for $70-80 \%$ of the cost of producing some livestock, most especially poultry Bolu and Balogun (1998). One of the key factors militating against the development of livestock is the high cost of feed resulting from a cumulative effect of cost of feed ingredients used in livestock feed production. For example, synthetic vitamin/mineral premix is an important feed ingredient that must be included in livestock feeds to produce a balance feed. Presently, this feed ingredient is imported and expensive. Direct method of reducing cost of production and increasing profitability has been traced to the usage of unconventional locally available and cheap feed ingredients. In Nigeria, concerted efforts have been given to source for alternative macro ingredients, e.g. corn, soy bean, groundnut cake etc., micro ingredients which contribute substantially to animal well-being in terms of providing essential micronutrients have however not receive same attention (Bolu, 2001).

Vitamin Premix is a mixture of essential micro- ingredients in livestock feeds because it is the major source of vitamin requirements of livestock. Current views on 
the provision of vitamin for animals and human food are those related to vitamin fortification especially where a deficiency or sub-optimal availability is suspected. Vitamin premixes are sold in the form of expensive synthetic analogues (Aduku, 1992). These products contain the active ingredients (30\%) and non-biodegradable stabilizers. The current global emphasis in animal production is the production of feeds that are free as much as possible of synthetic products (organic feed) owing to the deleterious side effects of consistent consumption of non-biodegradable synthetic products on both animal and human health (Casewell et al., 2007) . Detailed information on health hazards associated with the utilization of synthetic products in animal feeds has been documented (WHO, 1987). This information has been useful for organization and institutions engaged in the production and monitoring of food additives. They have also becomes useful tools of enlightenment regarding the effects of various synthetic additives in foods through the recommended Acceptable Daily Intakes (ADI), Maximum Residue Limits (MRLs), No- Observed- EffectsLevels (NOELs) toxicological effects and tolerable intakes of such additives, (WHO, 1987). Production and utilization of alternative natural vitamin source in animal production will not only substitute for the expensive (imported) synthetic form, but also reduce the overall cost of production, resultant health risk and environmental pollution.

Natural ingredients of interest in this study are vegetable such as Baobab leaf (Adansonia digitata leaf), Telfaria occidentalis (Ugwu), Celosia spp (Soko), Amaranthus cruentas (Tete), spices such as Ethiopian pepper (Xylopia aetiopica), and Red pepper (Capsicum frutenscen). Others are Yeast (Saccharomyces cerevicae), Rice bran, Palm oil, Fish liver oil and colostrum. High Performance Liquid Chromatography (HPLC) is now widely used regularly for the analysis of vitamins (Pozo et al., 1990). The advantages of this method of analysis lie in its speed, sensitivity and selectivity which is devoid of interference (Pozo et al., 1990). This study was aimed at determination of vitamin and mineral content of Baobab leaf (Adansonia digitata leaf), Telfaria occidentalis (Ugwu), Celosia spp (soko), Amaranthus cruentas (efo tete), spices such as Ethiopian pepper (Xylopia aetiopica), and Red pepper (Capsicum fructenscen); Yeast (Saccharomyces cerevicae), Rice bran, Palm oil, Fish liver oil and colostrums using High Performance Liquid Chromatography.

\section{Materials and Method Sources of Materials for Analysis}

The materials analysed included Baobab leaf (Adansonia digitata leaf), Telfaria occidentalis (Ugwu), Celosia spp (soko), Amaranthus cruentas (efo tete), spices such as Ethiopian pepper (Xylopia aetiopica), Red pepper (Capsicum frutenscen); Yeast (Saccharomyces cerevicae), Rice bran, Palm oil, Fish liver oil and colostrum. All the ingredients were collected within Ilorin, Kwara State, Nigeria. Fish Liver and abdominal oil by product was cold extracted from abdominal fat and liver of fish and kept in sealed polythene bags for 16 hours at a temperature of $-4^{\circ} \mathrm{C}$ for $24 \mathrm{hrs}$ prior to analysis. The vegetable leaves were bought fresh, air-dried for $36 \mathrm{hrs}$, cut into convenient size and ground into particle size ( $1 \mathrm{~mm}$ sieve) and stored prior to analysis. Spices used were bought in the dried form from the open market and ground to $1 \mathrm{~mm}$ sieve particle size. 


\section{Vitamin Assay Procedure}

Vitamin analysis was carried out at National Agency for Food, Drug Administration and Control (NAFDAC), Kaduna Regional Office, Kaduna State, Nigeria, using standard HPLC analytical procedures outlined for vitamin determination in Pharma and Food premixes as highlighted by Stadnick and Zona(1990). HPLC used was (Model: PU 4100 Liquid chromatograph. Phillip Analytical, Cambridge, UK) equipped with injection valve, double and mono piston pulse free pump, UV detector (Model PVE Unicam PU 4020), Flourescent detector (Model Varian 9075). Recorder (Model PM 825/A One line recorded), and integrator (Model PU 4815 Computing integrator, all of Phillip Analytical Cambridge, UK).

Vitamin A, D and E were determined according to the procedure of Pozo et al. (1990). Vitamin K (phytomenadione) was determined according to the procedure of Shino et al. (1984) and as modified by Fernandez and Crespillo (1990) while vitamin $\mathrm{B}_{1}, \mathrm{~B}_{2}, \mathrm{~B}_{6}, \mathrm{~B}_{12}$ niacin, and folic acid was determined using the procedure described by (Henninger et al., 1990) CaPantothenate was determined according to the procedure of Rhin (1990). Ascorbic acid was determined according to the procedures of Stadnick and Zona (1990), while carotene was determined according to AOAC (1990), respectively.

\section{Mineral Assay}

The mineral contents were determined by wet-ashing the samples with a mixture of hydrochloric acid and nitric acid, followed by flaming in an Atomic Absorption Spectrophotometer (Model: Philip Analytica PU 9100X) AAS using different lamps according to AOAC (1990).

\section{Results and Discussion}

The results of vitamin and mineral analyses are presented in Tables 1 and 2, respectively. Fish liver oil was found to be the most potent source of vitamins $\mathrm{A}, \mathrm{D}, \mathrm{E}$, and $\mathrm{B}_{12}$ represented by $9 \times 10 \mathrm{iu} / 100 \mathrm{~g}$., $48000 \mathrm{icu} / 100 \mathrm{~g}, 50 \mathrm{mg} / 100 \mathrm{~g}, 50 \mathrm{mg} / 100 \mathrm{~g}$, $40.56 \mathrm{mg} / 100 \mathrm{~g}$. The B-complex vitamins were evenly distributed among the ingredients analysed - Yeast contain more of thiamin $(9.4 \mathrm{mg} / 100 \mathrm{~g})$ and niacin (41.8mg/100g). Capsicum spp and Telfaria spp were found to be rich in ascobate. Xylopia aetiopica contain good amount of tocopherols, $25 \mathrm{mg} / 100 \mathrm{~g}$. Telfaria is found to be rich in ascorbic acid and also found to contain riboflavin, thiamin and niacin (Donatus and Nneka, 2007). Rice bran had the highest amount of pyridoxine, $28.6 \mathrm{mg}$ / $100 \mathrm{~g}$, while panthothenate was found more in the colostrum $(8.2 \mathrm{mg} / 100 \mathrm{~g})$ than other materials analysed. The mineral composition of the ingredients presented a fairly uniform potency. The results of the analysis are in agreement with NRC (1994) and that of Ngoddy and Ihenkoroye (1985). The composition of Capsicum spp was similar to the report of Pyke (1989) except for niacin, which was comparatively low $(3.8 \mathrm{mg} / 100 \mathrm{~g})$. It is however a good source of vitamin $\mathrm{C}$, thiamin, nicotinic acid and carotene. This observation is in agreement with the works of Hughes and Phillip (1989). The vitamin composition of the fish oil and its by - product was comparable to that reported by Pozo et al. (1990), which was found to be rich in vitamins A, D and E as also reported by Black et al. (1979). The analysis of the yeast is also comparable to (NRC, 1994) and is a good source of cobalamin. The values obtained however were different from those reported by Kutu et al. (1979). Yeast however, has been reported to be relatively good source of niacin, folate and thiamin (NRC, 1994). 
Vitamin and mineral analysis of fish liver oil, some locally avail able spices and vegetables

Table 1: An alysis of vitamin contents of the natural ingredients

\begin{tabular}{|c|c|c|c|c|c|c|c|c|c|c|c|c|c|c|}
\hline $\begin{array}{l}\text { Ingredient } \\
\mathrm{s}\end{array}$ & $\begin{array}{l}\mathrm{A} \\
\mathrm{iu} / 100 \mathrm{~g}\end{array}$ & $\begin{array}{l}\mathrm{D} \\
\mathrm{icu} / 10\end{array}$ & & $\begin{array}{l}\mathrm{E} \\
\mathrm{Mg} / 100 \mathrm{~g}\end{array}$ & $\begin{array}{l}\mathrm{K} \\
\mathrm{Mg} / 100 \mathrm{~g}\end{array}$ & $\begin{array}{l}\mathrm{B}_{1} \\
\mathrm{Mg} / 100 \mathrm{~g}\end{array}$ & $\begin{array}{l}\mathrm{B}_{2} \\
\mathrm{Mg} / 100 \mathrm{~g}\end{array}$ & $\begin{array}{l}\text { Niacin } \\
\mathrm{Mg} / 100 \mathrm{~g}\end{array}$ & $\begin{array}{l}\mathrm{B}_{6} \\
\mathrm{Mg} / 100 \mathrm{~g}\end{array}$ & $\begin{array}{l}\text { Folate } \\
\mathrm{Mg} / 100 \mathrm{~g}\end{array}$ & $\begin{array}{l}\mathrm{B}_{12} \\
\mathrm{Mg} / 100 \mathrm{~g}\end{array}$ & $\begin{array}{l}\text { Pantothen } \\
\text { ic acid } \\
\mathrm{Mg} / 100 \mathrm{~g}\end{array}$ & $\begin{array}{l}\text { Biotin } \\
\mathrm{Mg} / 100 \mathrm{~g}\end{array}$ & $\begin{array}{l}\text { Vit C } \\
\mathrm{Mg} / 100 \mathrm{~g}\end{array}$ \\
\hline $\begin{array}{l}\text { Fish Liver } \\
\text { Oil (by } \\
\text { product) }\end{array}$ & $9 \times 10^{6}$ & 48,000 & 30 & - & - & - & - & - & - & 40.5 & - & - & - & \\
\hline A. digitata & 4855 & - & - & 0.3 & 0.03 & 0.082 & 4.4 & 2.6 & 2.8 & 0.9 & 1.3 & 0.06 & Trace & \\
\hline $\begin{array}{l}\text { Telfaria } \\
\text { spp }\end{array}$ & 4302 & - & - & 0.4 & 1.0 & 0.25 & 5.0 & 3.2 & 3.2 & 0.14 & 1.6 & 0.18 & 1410 & \\
\hline $\begin{array}{l}\text { Celosia } \\
\text { spp }\end{array}$ & 3853 & - & - & 0.31 & 0.9 & 0.15 & 4.8 & 0.1 & 4.1 & 0.1 & 1.4 & 0.01 & 202.2 & \\
\hline $\begin{array}{l}\text { Amarantus } \\
\text { spp }\end{array}$ & 4132 & - & - & 0.22 & 1.1 & 0.3 & 10.1 & 0.12 & 5.1 & 0.12 & 1.6 & 0.11 & 379 & \\
\hline $\begin{array}{l}\text { Capsicum } \\
\text { spp }\end{array}$ & 3000 & - & - & 0.01 & 1.2 & 1.5 & 3.8 & 0.08 & 0.92 & 0.01 & 0.8 & 0.19 & Trace & \\
\hline Palm oil & $\begin{array}{l}90,00 \\
0\end{array}$ & - & - & - & - & - & & - & - & - & - & - & - & \\
\hline Milk & 1230 & 4.0 & 0.98 & 0.37 & 0.145 & 0.18 & 8.5 & 4.8 & 0.25 & 5.1 & 8.2 & 0.1 & trace & \\
\hline $\begin{array}{l}X . \\
\text { aetiopica }\end{array}$ & - & - & 25 & - & 0.13 & 0.21 & 5.6 & 4.6 & 3.1 & 0.8 & 1.4 & 0.1 & - & \\
\hline $\begin{array}{l}\text { Yeast } S . \\
\text { cereviciae }\end{array}$ & - & - & - & - & 9.4 & 0.4 & 41.8 & 4.1 & 3.8 & 4.8 & 1.11 & 0.2 & - & \\
\hline Rice Bran & - & - & - & - & 0.10 & 2.41 & 0.25 & 28.6 & 1.4 & 0.02 & 2.30 & 0.047 & 47 & \\
\hline
\end{tabular}

Table 2: Mineral Content of Natural Ingredients

\begin{tabular}{llllllll}
\hline Ingredients* & $\mathrm{Cu}(\%)$ & $\mathrm{Pb}(\%)$ & $\mathrm{Zn}(\%)$ & $\mathrm{K}(\%)$ & $\mathrm{Na}(\%)$ & $\mathrm{Ca}(\%)$ & $\mathrm{Mg}(\%)$ \\
\hline $\begin{array}{l}\text { Fish Liver Oil } \\
\text { by product) }\end{array}$ & - & - & - & - & - & - & - \\
$\begin{array}{l}\text { A. digitata } \\
\text { Telfaria spp }\end{array}$ & - & - & $<0.05$ & 0.11 & 0.5 & 1.95 & 4.4 \\
& 0.07 & - & 1.36 & 2.90 & 0.51 & 2.95 & 4.4 \\
Celosia spp & 1.12 & Trace & 0.26 & 2.60 & 0.97 & 2.52 & 4.8 \\
Amarantus spp & 3.0 & - & 1.40 & 5.13 & 1.10 & 5.04 & 1.09 \\
Capsicum spp & 0.055 & - & 0.01 & 2.40 & 0.63 & 1.50 & $<0.01$ \\
Palm oil & - & - & - & - & - & - & - \\
\hline
\end{tabular}


Celosia spp was reported to be rich in vitamin $\mathrm{A}$ and $\mathrm{C}$ and contain micronutrients similar to Amaranthus spp which is in support of that reported by Aletor and Adeogun (1995). Other results observed for Xylopia aetiopica, and colostrum composition were found to be new. The mineral analysis agreed with the reports of (NRC, 1994; Hughes and Phillip, 1989) except for some variations. The rice bran is a good source of riboflavin and this corresponds with the findings of NRC (1994) but the results of the findings did not show that rice bran contains some useful amount of mineral and vitamins.

The results of the analysis of vitamin and minerals of these materials showed that they are good sources of some essential micro nutrients and could be useful in formulating a natural vitamin premix for livestock. The findings of this work would serve as a valuable asset for feed manufacturer. It will also encourage the inclusion of these locally sourced products that are relatively cheap, and of ready availability as feed ingredients, this would further serve to reduce the cost of feed in the livestock sector save foreign earnings, improve the profit margin of farmers and livestock feed producer. On the overall, public health will also benefit from this paradigm shift in animal production.

\section{References}

Aduku, A.O. 1992. Practical livestock feeds production in the Tropics. S. ASEKOME and Co. Publishers. Zaria.

Aletor, V.M. A. and Adeogun, O.A. 1995. Nutrient and antinutrient components of some tropical leafy vegetables. Food Chemistry 53;375-397.

AOAC. 1990. Official methods of Analysis. $15^{\text {th }}$ edition. Association of Official Analytical Chemist. Washington D.C.

Black, K.L. Culp, B., Madison, D.,
Randal, O.O., and Lands, W.E.M., 1979. The protective effects of dietary fish oil on focal cerebral infraction Postaglandins. Medicine: 5 247-256.

Bolu, S.A. 2001. Response of broilers to natural Vitamin Premix. Ph.D Thesis, Department of A $n$ i $m$ a 1 Production, University of Ilorin, Ilorin, Nigeria.

Bolu, S.A. and Balogun, O.O. 1998. Comparative energy value of sorghum distiller's waste, maizecob and shea butter cake for pigs. Nig. J. of Anim. Prod. 25: 157-162

Casewell, M., Phillips, I. and Friis, C. 2007. The European ban on growthpromoting antibiotics and emerging consequences for human and animal

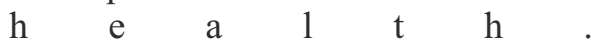
http://www.thepoultrysite.com/article s/49. Retrieved 27/08/07.

Donatus E.O and Nneka, S.U. 2007. Nutritive values and Phytochemical content of fluted pumpkin (Telfaria occidentalis ) Vegetable grown with different levels of NPK fertilizer. African crop science Conference Proceedings. Vol. 8. P 1759-1964.

Fernandez, F. and Crespillo, C 1990. Determination of vitamin K1 in dry vitamin feedstuffs HPLC Roche Analytica. A Manual of vitamin analysis.

Henninger, H., Brandaun, $K$ and Hoffman P. 1990. Simultaneous determination if water soluble vitamin $\mathrm{Bi}, \mathrm{B} 2, \mathrm{~B} 6, \mathrm{P}$ and Folic acid in dry vitamin feedstuff by HPLC, Roche

Analytical. A Manual of vitamin analysis.

Hughues , D., and Phillip , D. 1989. African garden and orchards: Growing vegetable and fruit. McMillian Publishers.Pg 68-85

Kutu, H.R., Gorgulu, M., Baykai, L., 
Unsal, I., Serbester, U., and Ozcan, N. 1997. Effect of replacing fish meals with dried molasses yeast (Saccharomyces cerevisiae) in the diet on the performance of broiler chicks. Br. Poultry Sci. 38: 30 -31.

Ngoddy, D.O. and Ihekoronye, I. 1985. Integrated Food Science Technology for Tropics. McMillian Publishers. Nigeria.

National Research Council 1994. Nutrient Requirementof Poultry. $9^{\text {th }}$ RevisedEdition. $\quad \mathrm{N}$ a $\mathrm{t}$ i o $\mathrm{n}$ a 1 Academy Press, Washington D.C.

Pozo, R.G., Saitua, E.S., Uncilia, I and Montoya, J.A. 1990 . Simultaneous determination by HPLC of fat soluble vitamins in Albcore (Tunnus alaunga) J. Food Sci. 55: 77-78.
Pyke, D. A. 1989. Limited resources and reproductive constraints in annuals. Functional Ecology 3(2): 221-228.

Rhim, P. 1990. Calorimetric Determination of Ca- Pantothenate in dry vitamin feedstuff Roche Analytica. A Manual of vitamin analysis.

Shino, M. 1988. Determination of endogenous vitamin $\mathrm{K} 1$ in plasma by HPLC. Analytical 113:393 -397.

Stadnick, R. and Zona, R. 1990. Determination of biotin in dry vitamin feedstuff by HPLC Roche Analytical. A Manual of vitamin analysis.

World Health Organization 1987. World Health Statistics Quarterly, Vol. 40 :1.

Received: $20^{\text {th }}$ October, 2011 Accepted: $3^{\text {rd }}$ F ebr uary, 2013 